\title{
Determinants and Consequences of Soft Budget
}

\section{Constraints: An Empirical Analysis using Enterprise-level}

\author{
Data in Transition Countries*
}

\author{
Céline Bignebat ${ }^{\dagger}$ Fabian Gouret ${ }^{\ddagger}$
}

December 4, 2007

\begin{abstract}
This paper presents empirical work grounded in the soft budget-constraint literature. A loan is soft when a bank cannot commit the enterprise to hold to a fixed initial budget and/or the timing of repayment. Using data collected by the EBRD (BEEPS 2002) in 26 transition economies, we analyze the determinants of managers' expectations of having a soft loan. In particular, we find that managers' expectations are lower when the initial financing requires collateral, and higher for larger firms and when firms had recently experienced financial distress. We also provide evidence that managers' expectations influence their price responsiveness.
\end{abstract}

JEL classification: C34, D84, G3, O12, P21.

Keywords: Soft budget constraint, Eastern Europe.

${ }^{*}$ We thank Mark Schankerman and two anonymous referees for valuable and detailed criticisms. We owe special thanks to Emmanuel Flachaire and Antoine Terracol for discussions of econometric issues during the revision process, as well as Mary Shirley and Kenneth Sokoloff for helpful comments on a preliminary version. We are grateful to Andrew Clark who has gone through the final version of the paper to improve the English. We also thank Antoine Berthou, Fabrice Defever, Guillaume Hollard, Claude Ménard, Olivier Musy, Boris Najman, Victor Polterovich, Koen Schoors, Julien Vauday and Vincent Vicard, as well as participants at the 9th Annual Conference of the International Society for Neo-Institutional Economics, MOISA-INRA seminar, the 6th Doctoral Meeting of International Economics and Finance, ROSES seminar, the 2006 PPF Workshop, the 2006 EACES Conference, and the 2006 Far Eastern Meeting of the Econometric Society. All remaining errors are ours.

${ }^{\dagger}$ MOISA-INRA, Montpellier, France, E-mail: bignebat@ensam.inra.fr

¥Université Paris-Est Marne-La-Vallée and Université Paris I Panthéon-Sorbonne, France, E-mail: Fabian.Gouret@malix.univ-paris1.fr 


\section{Introduction}

The term "soft budget constraint" (SBC) $\prod_{1}$ was first introduced by Kornai (1979) to shed light on economic behavior in socialist economies. It is now widely used to describe similar phenomena in post-socialist, developed and developing countries 2 The term alludes to a situation in which a loss-making firm is bailed out (by the government, a bank or another institution). Furthermore, the expectation of the firm manager as to whether the firm will be rescued from trouble is critical as this expectation will affect his behavior (Kornai, 1979). When the expectation is high, managerial effort to maximize profits is attenuated, the drive to innovate is weakened, and price responsiveness is dulled (Kornai, 1998). Despite considerable progress over the last decade in providing theoretical explanations of the SBC syndrom 3 , empirical research on its determinants is still in its infancy (Diankov and Murrell, 2002, Kornai et al.., 2003). The foremost difficulty is in operationalizing the notion of softness. In line with the work of Kornai, an empirical measure has to capture managers' expectations of being bailed out in case of trouble. SBC theorists thus argue that, for example, the subsidization of loss-making firms is not identical to SBC 4 Furthermore, they often highlight that empirical work is not closely grounded in theory (Kornai et al., 2003, p.1100).

With these concerns in mind, this paper uses survey data that elicits firms' expectations of receiving a loan-term extension if they fall behind in their bank repayments. We are therefore closer to the line of research initiated by Dewatripont and Maskin (1995) which considers that a SBC pertains when a bank cannot commit an enterprise to keep to a fixed initial budget and/or to maintain the timing of repayments specified in the contract. In Dewatripont and Maskin

\footnotetext{
${ }^{1} \mathrm{HBC}$ and BC respectively stand for "hard budget constraint" and "budget constraint".

${ }^{2}$ For example Huang and Xu (1999) believe that the SBC in the East Asian banking sector played an important role in the financial crisis of the late 1990s.

${ }^{3}$ See Kornai et al. (2003) for a survey of the formal theoretical literature on SBCs.

4 Qian and Roland (1998, p.1143) remark that "subsidization of loss-making enterprises is often an indicator of soft budget constraints. However, subsidies are not identical to soft budget constraints. There are cases in which firms receive subsidies but do not expect to be bailed out in cases of bad financial performance."
} 
(1995), the poor prospects of a project are discovered ex post by the bank, that is only after it has made a significant capital investment. However, by this point, the bank may do better in allowing the project to be completed by making a further infusion of capital. If this is the case, then the firm has a soft loan. This implies that the ex ante capacity of banks to apply accurate credit assessments is crucial. The evidence used in this study comes from the Business Environment and Enterprise Performance Survey 2002 (BEEPS 2002), which is jointly owned by the European Bank for Reconstruction and Development (EBRD) and the World Bank. The 2002 BEEPS survey covers nearly 6000 managers of firms across the countries of Eastern Europe, the former Soviet Union (FSU), and Turkey. We analyze the determinants of managers' expectations of having a soft loan using a censored bivariate probit model, given that some of the projects are not financed by banks. The selection equation, i.e. that which determines whether a firm is granted a loan or not, is also important as it determines the capacity of banks to apply a good prior screen based, one would assume, on an assessment of the default probability.

Our paper hence contributes to the progress of the SBC literature in at least two ways. First, our empirical work is close to Dewatripont and Maskin (1995) because we view soft budgets as the extension of credit even after the revelation of substandard performance in an already-financed investment project. Second, we clearly follow the idea that the SBC is related to expectations. To date, only Anderson et al. (2000) have used survey data which elicits managers' expectations. Anderson et al. survey nearly 250 enterprises that had gone through Mongolia's privatization program by 1995, asking managers what proportion of lost revenues the State would make up were losses to threaten the enterprise's ability to maintain employment. They examine various causes of soft budgets, and in particular State ownership. However, they do not consider soft budgets as the extension of credit when the firm falls behind 
in its bank repayments 5

Our work has three potential caveats. First, simply observing managers' expectations of receiving soft loans can generate misleading conclusions if the main instruments of rescue are fiscal (subsidies from the State budget or tax concessions). Nevertheless, a number of authors (Berglof and Roland, 1998, Dewatripont and Roland, 2000) have pointed out that loans have become the main means of softening the $\mathrm{BC}$ in several countries. In particular, some banks tend to give preference to distressed enterprises when allocating credit; see the evidence from Russia and the Ukraine (Huang et al., 2004), Romania (Coricelli and Diankov, 2001) and a collection of post-socialist countries (Schaffer, 1998). Second, we do not know whether our expectational approach measures real soft budgets or rather erroneous expectations. Note however that even were expectations to be erroneous, it is exactly these expectations that lead to inefficient enterprise decisions, as Anderson et al. (2000) highlight. The third and related issue is whether our subjective measure reflects softness, resulting in efficiency losses, or whether it reflects the concern of far-sighted managers who use soft loans to help their viable firms which might be experiencing temporary financial difficulties because of exogenous macroeconomic shocks. In this case, managers' behavior will not be distorted. The best test of these two alternative interpretations would be to examine whether the self-reported measure of softness leads to weakening firm performance and inefficient entreprise decisions by using panel data to disentangle macroeconomic and cyclical effects. Three rounds of the BEEPS questionnaire were conducted (in 1999, 2002 and 2005). However, BEEPS 2002 was the only round that included information on managers' expectations of soft budgets. It is thus impossible to construct a

\footnotetext{
${ }^{5}$ Two other important empirical papers provide indirect confirmation that the SBC is incorporated in managers' expectations. Using a sample of several hundred Chinese state firms over the period 1980-1994, Li and Liang (1998) demonstrate that losses were especially due to the redundancy of labor. This confirms that managers were convinced that they would be always be rescued. In a panel data set of Italian state-owned firms interviewed from 1977 to 1993, Bertero and Rondi (2000) show that managers' expectations evolved at the end of the 1980s: state firms responded to the decrease in subsidies and bank loans (probably due to European Union pressure to reduce state aid and to accelerate privatization programs) by increasing productivity and reducing overmanning.
} 
panel data set. Nonetheless, BEEPS 2005 does report whether firms were profitable in 2003, and whether they had implemented new technology over the past three years (i.e. in the exact period since the expectations of softness which were elicited in the 2002 version of BEEPS). Unfortunately, as will become clear in Section 5, too few of the firms surveyed in 2002 were also interviewed in 2005 for these two rounds to be merged to see whether our expectational measure leads to a weakening of market instincts. These are serious shortcomings that limit the analysis that can be undertaken. However, other features of the data balance the lack of a true time-series dimension. First, the extent of country variation is valuable in disentangling country-specific effects from the effect of firm characteristics on expectations of budgetary softness. Second, the survey asks managers how they would respond were the main supplier of their main material input to increase supply prices, assuming that other suppliers leave their prices unchanged. We show that if a manager believes that his firm will be helped out in case of trouble, he also answers that he will continue to purchase his main material input from the existing main supplier. This result suggests that if a manager is sure that the survival of his firm will not be jeopardized by insolvency, he becomes less responsive to prices, as SBC theory suggests.

The structure of the paper is as follows. Section 2 describes our framework, highlighting the determinants of the SBC that we will test. Section 3 presents our econometric methodology, and Section 4 presents the data and the main results. Section 5 provides some evidence that managers' behavior is distorted if they anticipate being rescued should they get into trouble. Finally, Section [ 6 presents a brief summary and conclusions.

\section{Theoretical framework}

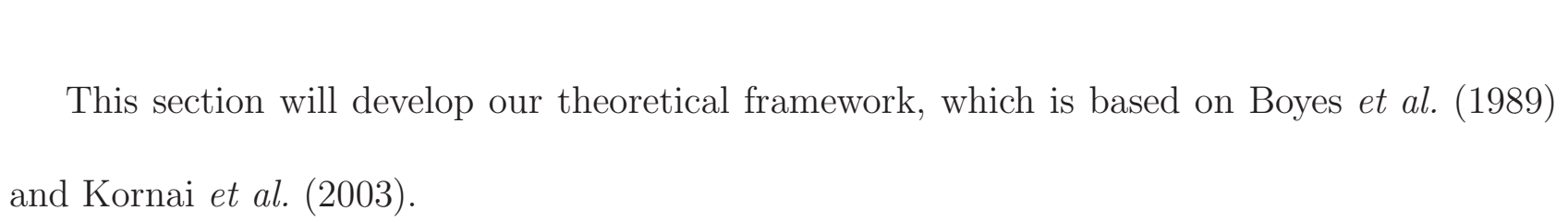


There are three periods, and two agents: a firm, headed by a manager, and a bank. Assume that the firm manager submits a project to the bank in period $t$. The bank must decide whether or not to grant a loan of an amount $l_{1}$. If it is funded, the project can yield a gross monetary return of $R_{g}\left(>l_{1}\right)$ by the end of period $t+1$. The firm can default on the loan. In this case the bank has two possibilities:

- To begin legal proceedings to take possession of the collateral of value $C o l$.

- Alternatively, the bank could refinance the project by injecting additional capital of $l_{2}$, extending the term of the loan or wait to obtain an expected gross return of $R_{p}$ in $t+2$. In this case, the loan is soft.

Notice that if the project defaults and

$$
R_{p}-l_{2}>C o l
$$

the loan is soft. Thus, the lower is collateral, the higher the probability of receiving a soft loan. Our data set allows us to test the following implication (see Section 4 for a presentation of the data):

Testable Implication 1 The manager's expectation of having a soft loan is lower when the initial financing requires collateral.

However, note that the firm will receive a soft loan if and only if the bank has not been able to apply a good screen in period $t$. The bank initially knows that the loan has two possible outcomes, that can be described by a Bernoulli trial:

$$
\pi=\left\{\begin{array}{lll}
R_{g}-l_{1} & \text { with probability } & p \\
\max \left\{R_{p}-l_{2} ; \mathrm{Col}\right\}-l_{1} & \text { with probability } & (1-p)
\end{array}\right.
$$


If the bank knows all of the parameters of the trial, it can establish a credit-approval requirement for projects. The loan is approved if the prior probability of success $p$ is such that:

$$
p \geq \frac{l_{1}-\max \left\{R_{p}-l_{2} ; C o l\right\}}{R_{g}-\max \left\{R_{p}-l_{2} ; C o l\right\}} \equiv \bar{p}
$$

The firm will receive a soft loan if $p \geq \bar{p}$ and $R_{p}-l_{2}>C o l$. Remark that the SBC syndrome represents, in statistical-inference terminology, a type-II error: the bank fails to reject the initial funding of a poor project. Hence, the capacity of the bank to apply accurate credit-assessment in period $t$ is crucial because it can reduce the SBC problem.

This framework can be extended to include other circumstances that lead to soft budgets. First, the bank's ownership structure might matter. While a private bank is presumably in the business of maximizing profit, this is not so much the case for a state-owned bank. A state bank is controlled by the government and, therefore, its financing decisions reflect the government's objectives. SBC theories explaining that a state bank will allow firms in trouble to complete a bad project are of two kinds. First, if the government is benevolent, the state bank maximizes overall social welfare. So a troubled firm will be bailed out if its demise might cause external damage greater than the cost of rescue. For example, a state bank may choose to bail out an unprofitable monopoly, because the elimination of its production may upset other firms as well, and precipitate serious loss to society (Segal, 1998). Second, if the government values the firm for its political support, it will consider the political benefit of keeping project workers employed. Kornai et al. (2003, p.1110) model these two arguments in the same way. They consider a parameter $E(>0)$ which might be the political benefit of keeping workers employed, or alternatively the external effect of a project on the rest of the economy 6 A state-owned

${ }^{6}$ If $E$ is the political benefit of keeping project workers, the model could be interpreted along the lines of Bovcko et al. (1996), who associate the SBC syndrome with intervention by politicians in firms. In their model, politicians view softness as something desirable because it allows them to influence firms' employment policies. In particular, they show that such influence is fostered by state ownership because politicians own the control rights to the firms. 
bank will refinance a project if $R_{p}+E-l_{2}>$ Col. This condition is less demanding than $R_{p}-l_{2}>$ Col. We thus obtain the second testable implication:

Testable Implication 2 A manager with a loan from a state-owned bank has a higher expectation of soft loan than a manager with a loan from a private bank.

We now assume that there is a third player, the government, and that the bank is private. In this case, if the firm represents political capital for the government (the firm is state-owned, too big to fail, or a monopoly), even a private bank might extend the term of the loan to the firm or wait if the private bank expects that the government will act as the ultimate guarantor of the firm in case of trouble.

Testable Implication 3 A firm which represents political capital for the government is more likely to have a soft loan. Furthermore, a firm with political capital is more likely to obtain a loan.

\section{Econometric methodology}

Given the model sketched above and the data at our disposal (described in the following section), expectations of soft loans will be censored, since banks will not grant loans to all applicants. Consequently a bivariate probit with censoring is the natural framework for our empirical analysis. This econometric model was first explored by Van de Ven and Van Praag (1981). Since then, it has been applied by Boves et al. (1989) and Greene (1992, 1998) to develop statistical models of credit-scoring, that is the empirical prediction of loan default.

Suppose that $Y_{i}^{*}$ is a continuous latent variable reflecting the degree of softness of the budget constraint of enterprise $i$. Then

$$
Y_{i}^{*}=X 1_{i} \beta+\epsilon_{i}
$$


where $X 1_{i}$ is a vector of variables that are considered as potential determinants of managers' expectations: the collateral, the number of competitors, and the size and ownership of firm $i$. $\epsilon_{i}$ is an error term. We call this equation the Soft equation. We consider the binary response of enterprise $i$ regarding expectations of having a soft loan:

$$
\begin{aligned}
& \text { Soft }_{i}=1 \quad \text { if } \quad Y_{i}^{*}>0 \\
& \text { Soft }_{i}=0 \quad \text { if } \quad Y_{i}^{*} \leq 0
\end{aligned}
$$

The dependent variable, however, is censored, since only applicants that have received credit are observed. To put this in a familiar context, the selection equation is:

$$
\operatorname{Loan}_{i}=\left(Z_{i} \gamma+\eta_{i}>0\right)
$$

where $\operatorname{Loan}_{i}=1$ if the firm $i$ obtains a loan, and 0 otherwise, $\eta_{i}$ is an error term, and $Z_{i}$ includes the traditional variables of credit-scoring models: the firm's and manager's characteristics. This selection equation, called the Loan equation, is fundamental since the capacity of the banking system to apply accurate lending criteria is crucial. Finally, we assume that the error terms $\epsilon_{i}$ and $\eta_{i}$ have a bivariate normal distribution with zero means and correlation $\rho_{\epsilon \eta}$.

$$
\left(\begin{array}{c}
\epsilon_{i} \\
\eta_{i}
\end{array}\right) \sim \text { bivariate normal }\left(\left(\begin{array}{l}
0 \\
0
\end{array}\right),\left(\begin{array}{cc}
1 & \rho_{\epsilon \eta} \\
\rho_{\epsilon \eta} & 1
\end{array}\right)\right)
$$

The assumption that $\operatorname{Var}\left(\epsilon_{i}\right)=\operatorname{Var}\left(\eta_{i}\right)=1$ is the standard normalization for probits. Equations (4)-(6) are the general specification of a bivariate probit with censoring. The probability of interest is the probability of expecting an extension of the term of the loan in case of trouble, 
given that a loan has been obtained, which is:

$$
\operatorname{Prob}\left[\text { Soft }_{i}=1 \mid \operatorname{Loan}_{i}=1\right]=\frac{\Phi_{2}\left(X_{1 i} \beta, Z_{i} \gamma, \rho_{\epsilon \eta}\right)}{\Phi\left(Z_{i} \gamma\right)}
$$

where $\Phi_{2}$ and $\Phi$ denote the bivariate standard normal c.d.f. and univariate standard normal c.d.f., respectively.

\section{Estimation results}

\subsection{Data and model specification}

The data used in this paper are drawn from BEEPS 2002. As noted in the introduction, other waves of the BEEPS were conducted in 1999 and 2005, but BEEPS 2002 is the only round that elicited manager's expectations of soft loans. The use of multiple waves would have allowed stronger identification of the determinants of who obtains such loans. Nonetheless, the information collected from firms across all sectors in a large number of economies potentially offers significant new results. We first describe the main features of the data set and then the issues raised by our approach.

BEEPS 2002 is a survey of 6367 firms in 26 transition economies7, as well as Turkey, and was conducted in the first half of 2002. It was collected on the basis of face-to-face interviews with owners, managers or finance officers via site visits by surveyors trained according to a standardized methodology. The sample was structured to be representative in each country with specific quotas in terms of size, sector, ownership and export orientation (MEMRB Custom Research Worldwide, 2002, Hellman and Kaufmann, 2002). We restrict our sample to firms in transition economies, i.e. we drop the firms located in Turkey (511 obser-

\footnotetext{
${ }^{7}$ The 26 countries are Albania, Armenia, Azerbaijan, Belarus, Bosnia, Bulgaria, Croatia, the Czech Republic, Estonia, Georgia, Hungary, Kazakhstan, Kyrgyzstan, Latvia, Lithuania, Macedonia, Moldova, Poland, Romania, Russia, Slovakia, Slovenia, Tajikistan, the Ukraine, Uzbekistan and Yugoslavia.
} 
vations). This sample of firms is called the BEEPS II sample in Table 1, where descriptive statistics are presented.

\section{-Table 1 about here-}

We have two key pieces of information in this survey:

- Whether the firm has obtained a loan (the Loan variable).

- And, if this is the case, whether the firm believes the loan is soft (the Soft variable).

With respect to the Loan equation, a relevant question for our analysis is whether we should consider all the firms of the BEEPS II sample or rather only loan applicants. Here we set an important part of these concerns to one side for the moment and provide the following argument in favor of dropping all the firms that have not applied for a loan. By doing so, the Loan equation is meant to reflect the credit assessment carried out by banks. If we instead retain all of the firms in the BEEPS II sample, the estimated coefficients from the selection equation will not distinguish between a credit-supply effect (the bank accepts or rejects an application) and a credit-demand effect (whether the firm has submitted a project).

The problem here is that we do not know directly from the survey whether a firm which does not have a loan had actually applied for one. However, we do know whether the firm faces major obstacles in obtaining financing from banks. Consequently, we assume that firms which do not currently have a loan and which say that they do not face major financing obstacles have not applied. We thus drop from the survey all of these latter firms (1225 firms, Turkish firms excluded) and consider that the applicants consist of firms which have obtained a loan ( $\mathrm{N}=2368)$ and those firms which do not have a loan but who say that they face major obstacles in obtaining financing from banks ( $\mathrm{N}=2253)$. Our final sample is thus composed of 4621 loan applicants 8

\footnotetext{
${ }^{8}$ The initial data set is composed of 6367 firms. We first drop 511 Turkish firms. We also drop 1225 firms which did not submit a proposal to a bank. Finally, 10 officials do not answer whether they have obtained a loan or not.
} 
This sample of 4621 firms is called the original sample in Table 1. Some observations will be dropped due to missing answers. Finally, our estimation sample is composed of 3531 firms, as shown in Table 19 We do not believe that the missing observations bias our results, as the summary statistics in the original and estimation samples look very similar.

The BEEPS 2002 question eliciting expectations concerning the bank's reaction were the firm to get into trouble is the following:

If your firm were to fall behind in its bank repayments, which of the following would best describe how you would expect the bank to react? [1] Do nothing, [2] Extend the term of the loan without changing the conditions, [3] Extend the term of the loan but increase the interest rate, [4] Begin legal proceedings to take possession of assets, [5] Don't know.

\section{-Table [2 about here-}

Table 2 shows the responses given by enterprises. None of the managers answers that [5] they do not know. We assume that $\operatorname{Soft}_{i}=1$ if the manager of the firm $i[1]$ expects the bank will do nothing or [2] expects the bank to extend the term of the loan without changing the conditions. Indeed, in these two cases, the loan is soft almost by definition. However, Soft $_{i}=0$ if the manager of firm $i$ expects that [3] the bank will extend the term of the loan but increase the interest rate, or [4] the bank will begin legal proceedings to take possession of assets. Considering that $S_{o f t}=0$ when the manager of the firm $i$ expects [3] is defensible, but admittedly arbitrary. Consequently, we shall also present a set of robustness checks with Soft $=1$ also when managers answer [3].

Following the framework of section 2, there are five sets of regressors in the Soft equation in which we are mainly interested:

\footnotetext{
${ }^{9}$ The loss of observations caused by missing answers is around $23 \% \simeq\left(\frac{4621-3531}{4621}\right)$ of the original sample.
} 
- We consider the variable Collateral to test implication 1 Collateral $=1$ if the initial financing required collateral, and 0 otherwise.

- For implication 2 we consider a set of dummy variables that reflects the ownership type of the main financial source of the firm. However, we note that the BEEPS data set does not specify if the loan under consideration comes from the main financial source of the firm. We will need to keep this problem in mind when analyzing the results.

- For implication 3, we first consider a set of dummy variables that depicts the type of the firm's main shareholder. In particular, we expect managers of state firms to be more likely to anticipate an extension of the term of their credits when they fall behind in their bank repayments. Furthermore, a state firm might represent political capital, so it is possible that it is more likely to be granted a loan.

- Second for implication [3 we also consider a set of dummy variables that describes the firm's size. We expect that the belief that the loan is soft to be greater for large firms. Furthermore, the bigger the firm, the greater the probability that it represents political capital, so the higher is the probability of having its loan application accepted initially.

- Third for implication 3 a set of dummy variables representing the number of competitors is introduced.

We also include various control variables that might explain managers' expectations. First, we consider managers' age and education via dummy variables 10 Second, we include a dummy variable indicating whether the firm had had financial difficulties in the recent past, and the percentage of sales by customers (the government, multinational firms, or others). In addition

\footnotetext{
${ }^{10}$ As in the BEEPS survey, we group age into 6 categories: 20-29, 30-39, 40-49, 50-59, 60-69, and 70 or more. Education is grouped into 6 categories: did not complete secondary school, secondary school, vocational training, some university training, completed university degree, and completed higher university degree.
} 
to these variables, we control for sectoral effects, for which we use the eight-sector categorization proposed by BEEPS11, and country-specific effects.

The right-hand side variables of the Loan equation reflect the characteristics of a firm and its manager. Thus they are mainly the same as those in the Soft equation $\square$ Technically, identification of the parameters in the Soft equation is assured by the simple non-linearity of the two equations in the bivariate probit (as in Boves et al., 1989, p.9). However, this is likely better handled via an exclusion restriction, i.e. a variable that ideally influences the Loan equation but not the Soft equation. Although this would be helpful for identification, it might be argued that anything that plausibly makes the bank more willing to lend to the firm should also make it more willing to refinance it. However, this argument is not valid because it is not the bank's decision to refinance a project that we look at in the Soft equation, but rather the manager's belief of obtaining an extension of the term of the loan were the firm to get into trouble. Some characteristics that plausibly make the bank less willing to lend to the firm might make the firm more willing to expect an extension of the term of the loan in case of trouble. For example, ceteris paribus we expect the bank to reject loan applications from firms that have been in trouble in the recent past. However, if a firm that was unprofitable obtains a loan, it could reveal that "the growth of the firm starts to break away from its financial situation [and] the manager of the firm may feel that the probability has grown that his firm would also survive despite a financial failure caused by a wrong investment" (Kornai, 1979, p.807). So a firm recently in trouble is less likely to obtain a loan but, if it obtains one, it will be more likely to expect an extension in case of trouble.

Based on the framework in section 2, a good exclusion restriction would be a signal that

\footnotetext{
${ }^{11}$ The eight sectors are: i) mining and quarrying, ii) construction, iii) manufacturing, iv) transport and storage, v) Wholesale, retail, repairs, vi) Renting and business services, vii) Hotels and restaurants, and viii) other.

${ }^{12}$ However, remark that for the Soft equation we have information on more variables: the main financing source, that we assume to be the bank that granted the loan, and if the loan required collateral.
} 
increases the prior probability $p$ that the project submitted by the firm is a good one (see equation (3). If the project defaults, the bank will realize that the information contained in the signal was wrong. Consequently, the bank will not consider the signal in its decision to extend the term of the loan. A possible, if imperfect, candidate is then an external audit on the firm's financial statements. This produces an unbiased and independent evaluation of the firm's financial statement and on the value of its projects. However, if the project defaults, then the capital budgeting, that is the planning process used to estimate the size and timing of cash flows, was incorrect. Seen this way, there is no reason for the bank to consider the external audit in its decision whether to extend the term of the loan. An obvious criticism of this exclusion restriction is that external auditing might be seen as a positive signal about the quality of the firm's management and governance, even if the firm defaults. In particular, a viable firm might be confronted with illiquidity because of an unexpected macro shock. In this case, the bank might understand that the decline in the enterprise's fortunes is only temporary and might consider the external audit in its decision to extend the term of the loan. Nevertheless, with 26 countries covered by our sample, we can address this issue by exploiting the cross-country dimension to control for macroeconomic-specific effects via country dummies. We also include two other identification variables in the selection equation: a dummy variable indicating whether the firm uses international accounting standards (IAS), and a dummy variable showing whether some employees received training in 2001 (managers or workers). These variables can also be perceived as signals of a dynamic firm (however, we remark that none of these three exclusion variables is statistically significant when we include them in a probit estimation of the Soft equation). 


\subsection{Results}

The bivariate censored probit estimates for the loan granting decision (Loan) and the expectation of an extension in case of trouble (Soft) are shown in Table 3 . Estimates for this model are obtained by maximizing the following log-likelihood:

$$
\begin{aligned}
\ln (L)= & \left\{\begin{array}{l}
\sum_{\substack{\text { Loan }_{i}=1 \\
\text { Soft }_{i}=1}} \ln \left(\operatorname{Prob}\left[\text { Soft }_{i}=1 \mid \text { Loan }_{i}=1\right] \operatorname{Prob}\left[\operatorname{Loan}_{i}=1\right]\right) \\
+\sum_{\substack{\text { Lan }_{i}=1 \\
\text { Soft }_{i}=0}} \ln \left(\operatorname{Prob}\left[\text { Soft }_{i}=0 \mid \operatorname{Loan}_{i}=1\right] \operatorname{Prob}\left[\operatorname{Loan}_{i}=1\right]\right) \\
+\sum_{\text {Loan }_{i}=0} \ln \left(\operatorname{Prob}\left[\operatorname{Loan}_{i}=0\right]\right)
\end{array}\right. \\
= & \sum_{\substack{\text { Loan }_{i}=1 \\
\text { Soft }_{i}=1}} \ln \Phi_{2}\left(X 1_{i} \beta, Z_{i} \gamma ; \rho_{\epsilon \eta}\right)+\sum_{\substack{\text { Loan }_{i}=1 \\
\text { Soft }_{i}=0}} \ln \Phi_{2}\left(-X 1_{i} \beta, Z_{i} \gamma ;-\rho_{\epsilon \eta}\right)+\sum_{\operatorname{Loan}_{i}=0} \ln \Phi\left(-Z_{i} \gamma\right)
\end{aligned}
$$

There are several types of marginal effects which we would like to evaluate in the baseline model of Table 3. As noted above, the probability of interest in this model is that of expecting an extension of the term of the loan in case of trouble given that a loan is accepted. Thus, the first type of marginal effect (or discrete change for dummy variables) to evaluate is $\frac{d \operatorname{Prob}[\text { Soft=1|Loan=1 }]}{d X 1}$. We might also be interested in the loan-granting decision, so the second type of marginal effect is $\frac{d \operatorname{Prob}[\operatorname{Loan=1}]}{d Z}$. Given that we have excluded all of the firms which were not loan applicants, $\frac{d \operatorname{Prob}[\text { Loan=1] }}{d Z}$ shows which firms are more likely to have their credit accepted or denied. Table 4 presents these marginal effects at the mean values.

\section{-Tables 3 and 4 about here-}

Tables A1, A2 and A3 in the Appendix present the marginal effects from some specifications that are slightly different from that in the baseline model of Table 3 In Table A1 we present the marginal effects of various specifications where some of the explanatory variables in the baseline model have been excluded (so with the exception of these excluded explanatory variables, we control for all of the other variables in the specification of Table 3 country dummies, sector of activity, percentage of sales by customers etc.). In Table A2, we divide the data set into CIS and 
non-CIS firms. In Table A3 we ask how the results are affected if we assume that Soft $=1$ when managers expect that the bank will extend the term of the loan but also increase the interest rate if they fall behind with their bank repayments. At the bottom of each specification we report the difference(s) from that in Table 313

\section{Collateral: Testable Implication [1}

In line with the framework presented in section 2, managers of firms whose initial financing required collateral are less likely to expect an extension of the term of their loan in case of financial trouble. As Table 4 indicates, they are 8.2 percentage points less likely to expect an extension in case of trouble. The negative effect of the collateral falls to 3.7 percentage points when we use the alternative definition of Soft in Table A3.

\section{Ownership of the Bank: Testable Implication 2}

Surprisingly, there is no statistically significant difference between the various possible financing sources. This result is perhaps due to the fact that we do not know whether it is the main financing source which has granted the loan.

\section{The Size of the Firm: Testable Implication 3}

The first column of Table 4 indicates that the larger is the firm, the more likely it is to have its loan application accepted. Furthermore, firms with less than 50 employees are 9.5 percentage points less likely to expect soft budgets.

\section{Ownership of the Firm: Testable Implication [3]}

Ownership effects are not very clear: in contrast with our priors, state-owned enterprises do not seem to perceive soft budgets any more strongly than do other enterprises. Furthermore, state ownership decreases the probability of having a loan application accepted by 5.2 percentage points at mean values. However, when we divide the data set into CIS and non-CIS firms in

\footnotetext{
${ }^{13}$ We exclude Manager age and education dummies when we divide the data set into CIS and non-CIS countries, and Manager education dummies when we consider the alternative definition of Soft. The reason is that the number of firms in certain categories becomes too low to obtain consistently significant results.
} 
Table A2 the results show a clear difference. First, state ownership is found to have a significant and positive impact on expectations of soft loans in CIS countries, but no effect in non-CIS countries. Second, workers' and managers' ownership are also important drivers of beliefs about soft budgets in CIS countries. These results are compatible with Kornai (2000, 2001), and could be explained by the political role of worker- and manager-owned firms, especially at the local level in CIS countries.

\section{Number of Competitors: Testable Implication 3}

The number of competitors influences the probability of having the loan application accepted, but does not seem to influence the probability of having a soft loan.

\section{Past firm performance}

As shown in Table 4 firms which were unprofitable in 2001 have a 4.4 percentage point lower probability of having their application accepted. This result might suggest that there has been an amelioration of the banking system since the Nineties in transition economies 14 However, when we divide the data set into CIS and non-CIS firms in Table A2, the results again reveal sharp differences. Managers of firms which were in financial distress in 2001 are less likely to have an application accepted in non-CIS countries, but not in CIS countries. Furthermore, firms which were unprofitable in 2001 in CIS countries are 22.1 percentage points more likely to believe that they will have an extension of the term of their loan in case of financial difficulties.

Lastly, the estimate of $\rho_{\epsilon \eta}$ that maximizes the bivariate probit likelihood is -0.413 , with a standard error of 0.541. Two remarks are required here. First, the Wald statistic for the test of the hypothesis that $\rho_{\epsilon \eta}$ equals zero is 0.582 . This is not significant, so the hypothesis that $\rho_{\epsilon \eta}$ equals zero cannot be rejected. This result might seem counter-intuitive, given the setting: surely Soft and Loan are correlated? Note that our finding does not contradict this proposition: $\rho_{\epsilon \eta}$ measures the correlation between the disturbances in the equations, that is the

\footnotetext{
${ }^{14}$ Various studies have shown that banks tend to favor firms in trouble when allocating credit (e.g., Bonin and Schaffer, 1995, Coricelli and Diankov, 2001, Huang et al., 2004).
} 
correlation between Soft and Loan after the influence of all of the factors included has been

accounted for 15 Thus, when we exclude a set of variables from the baseline specification that have a large impact on Loan and Soft (say firm size as in specification [A] of Table A1), the estimate of $\rho_{\epsilon \eta}$ is -0.504 and is significant at the 5 percent level.

The second remark concerns the negative value of the estimate of $\rho_{\epsilon \eta}$ in our baseline specification, as well as in the specification of Table A1. As noted in subsection 4.1, we might have thought that anything that plausibly makes the bank more willing to lend to the firm should make the firm more willing to expect an extension. If this were true, unmeasured factors which contribute positively to the obtention of a loan would positively influence the expectation of an extension in case of trouble. (In the extreme case, were the explanatory factors influencing selection and the subsequent outcome of interest to be identical, $\rho_{\epsilon \eta}$ would equal one). On the contrary, our estimate of $\rho_{\epsilon \eta}$ is always negative.

\subsection{Do we really have to exclude firms that are not loan applicants from our sample?}

Up to now, we have considered the relevant sample for our analysis to be that where all of the firms that were not loan applicants are dropped. This is a simple way of seeing how loans are denied by banks. However, this subsection suggests that this sample might produce an upward-biased estimate of the probability of expecting a soft loan for a firm selected at random from the full population of firms.

The reason follows from Dewatripont and Maskin (1995). In their model, the quality of the project is known by the manager in period $t$, but not by the bank. There is thus asymmetric information. Faced with a poor project in period $t+1$, the bank could begin legal proceedings

\footnotetext{
${ }^{15}$ Greene (1992, p.21) makes a similar remark regarding the interpretation of the correlation coefficient in bivariate probit and Heckman selection models.
} 
to take possession of assets, in which case the manager receives a negative private benefit (representing, say, the manager's loss of reputation). Alternatively, the bank could extend the term of the loan. In this latter case the gross return in period $t+2$ is $R_{p}$ and the manager's benefit is positive: as assumed by Dewatripont and Maskin (1995), a manager can extract more from a project the longer it continues. Consequently, when the manager has to decide at the beginning of period $t$ whether or not to submit his project, he submits the project if he expects that he will have an extension in case of trouble. Thus, for a given set of attributes, $X 1$, applicants might be more likely to expect a soft loan than otherwise similar firms chosen randomly from a population containing a mixture of firms which have applied and which have not. Of course, submitting a project does not imply that the firm will obtain a loan. But in some transition economies, there is evidence that banks do not apply accurate lending criteria (Berglof and Bolton, 2002, pp.82-84). Since loan recipients do not pass an accurate prior screen, the decision to apply also determines the selection process. Following this line of reasoning, we should use all of the firms in the BEEPS II sample.

An elegant possibility would be to use a trivariate probit specification to model this. A trivariate probit would extend our model to three outcome variables by simply adding an Application equation $\left(\right.$ Application $_{i}=1$ if the firm $i$ has applied, 0 otherwise) 16 The obstacle to such an extension is practical. Some progress has been made on the evaluation of higher than bivariate normal integrals. But as Greene (2003, p.714) highlights, existing results are not sufficient to allow accurate and efficient evaluation for more than two variables in a sample of even moderate size 17

\footnotetext{
${ }^{16}$ For a given firm, $S o f t_{i}$ would not be observed unless $\operatorname{Loan}_{i}$ equalled one, and $\operatorname{Loan}_{i}$ would not be observed unless Application $i$ equalled one. The error terms $\epsilon_{i}$ (for the Soft equation), $\eta_{i}$ (for the Loan equation) and, say $\mu_{i}$ (for the Application equation), would have a trivariate normal distribution with zero means, unit variances, and correlations $\rho_{\epsilon \eta}, \rho_{\epsilon \mu}, \rho_{\eta \mu}$. Were $\rho_{\epsilon \mu}$ not to equal 0, the first selection equation, that is the decision to submit a project or not (the Application equation), would be applicable.

${ }^{17}$ We made a number of attempts, computing the trivariate normal cumulative density functions that are implied by such a model with the GHK (Geweke-Hajivassiliou-Keane) smooth recursive conditioning simulator, as in Cappellari and Jenkins (2006). A model was evaluated using Maximum Simulated Likelihood techniques (MSL). However, we did not obtain convergent estimators. We believe that one important reason is the large
} 
As a substitute, we propose a bivariate probit with censoring using the BEEPS II sample. The outcome of particular interest is still the Soft equation. But now the selection equation is neither a credit-supply equation (that is the bank's decision whether to fund a submitted project) nor a credit-demand equation (that is the manager's decision whether to submit a project); it is rather a reduced-form relationship.

Table 5 presents the marginal effects of some of the key variables in three different specifications. In the first, we consider all the firms in the BEEPS II sample. The variables included in the Loan and Soft equations are the same as in Table 3 specification. Note that there is some loss of observations: the BEEPS II sample is composed of 5856 firms, but some of these do not answer some of the questions. Finally the sample consists of 4537 observations, as reported at the bottom of Table 5. In the second and third specifications, we divide the BEEPS II sample into CIS and non-CIS firms. We also control for all of the variables in Table 3, except the Manager age and education dummies 18

The results are broadly the same as those presented previously. The main difference from the results in subsection 4.2 concerns firms owned by managers in CIS countries. These were 15 percentage points more likely than foreign firms to expect an extension in case of trouble in Table A2 in Table 5 , this effect increases to 21.5 percentage points.

\section{- Table 5 about here-}

number of dummy variables in our database. For an extensive discussion of the principles underlying the GHK simulator and MSL estimation, see Gouriéroux and Monfort (1995) and Haiivassiliou et al. (1996).

${ }^{18}$ The reason is the same as in Table 12 the number of firms in certain categories becomes too low to obtain consistently significant results. 


\section{Do firms that (believe they) have a soft loan behave}

\section{differently?}

One important issue has not been addressed: this is whether our variable Soft measures softness, resulting in efficiency losses, or whether it reflects the concerns of efficient managers who expect a loan extension to help their viable firm weather hard times (even though sectoral and country dummies in the preceding section should partly capture this effect). A firm may suffer temporary financial difficulties due to macroeconomic or sectoral shocks, with no effect on the effort exerted by the firm. This raises the question: will firms reporting themselves as having a soft loan also distort their behavior?

Theory tells us that the SBC syndrome will produce at least three characteristic distortions. i) If the firm is sure that it will be rescued in case of trouble, its pursuit of profits will be feebler, as it needs to strive less hard in order to survive. ii) If managers expect to be rescued, there will be a weakened impetus to adopt new technologies. iii) If the firm is sure it will be rescued in case of trouble, it will become less responsive to the prices of its inputs.

BEEPS 2005 provides information on the profitability of the firm in 2003 and on the adoption of new technology between 2002 and 2005. Thus, the best test of i) and ii) would be to examine whether self-reported measures of softness in 2002 lead to weaker enterprise performance and less adoption of new technologies by merging BEEPS 2002 and BEEPS 2005. The problem is that only 1399 of the 9098 firms surveyed in 2005 (Turkish firms excluded) were also surveyed in 2002 (i.e. 15.37\%). Of these 1399 firms, Soft is observed for less than 490 firms, that is fewer than 19 firms by country on average 19 The low numbers of BEEPS 2002 firms that either were found by the BEEPS 2005 interviewers, or if found, agreed to be interviewed, raises important questions about selection bias. It also produces technical problems of convergence

\footnotetext{
${ }^{19}$ Remark that these observation numbers are actually optimistic, as we do not consider the loss of observations caused by missing values.
} 
and the inability to use a satisfactory number of controls. This strategy has therefore been abandoned in the circumstances.

However, using only the BEEPS 2002 survey allows us to test iii): that the SBC syndrome dulls the price responsiveness of firms. More precisely, the question is as follows:

If the main supplier of your main material input increased its supply price by $10 \%$ above what you pay at present (after allowing for inflation), how would you respond assuming that alternative suppliers if any left prices and other terms unchanged? [1] Purchase the same amount of the main material input from the existing main supplier, [2] Continue most of the purchases from the existing main supplier, [3] Purchase most of this material input from alternative suppliers, but continue some purchases from the existing main supplier, [4] Purchase all of this material input from alternative suppliers.

Price responsiveness is examined by considering the variable $P R . P R_{i}=0$ if the firm $i$ believes it will not be responsive to prices, i.e. if [1] it will purchase the same amount of the main material from the main supplier or if [2] it will continue most of the purchases from the existing main supplier. In these two cases, the firm is not responsive to the prices of its inputs; $P R_{i}=1$ if firm $i$ will purchase [3] most or [4] all of its material input from alternative suppliers.

Of course, $P R$ is only a self-reported piece of information on potential behavior: it is not a fact. However, if the variable Soft reflects an important element of reality, a firm that expects that its bank will not engage in legal proceedings if it falls behind in its bank repayments is also less likely to believe it will purchase most of (or all) its material inputs from alternative suppliers if the price increases. Formally, we have a probit equation which is:

$$
P R_{i}=\left(\text { Soft }_{i} \alpha+V_{i} \delta+\nu_{i}>0\right)
$$


where $V_{i}$ is a vector of control variables and $\nu_{i}$ is an error term. This underlying relationship between $P R$ and Soft is only observed if Loan equals one. Thus the relationship between PR and Soft is observed if:

$$
\operatorname{Loan}_{i}=\left(Z_{i} \gamma+\eta_{i}>0\right)
$$

There are two probabilities of interest. The first is the probability of changing supplier should the current supplier increase prices given that the firm has a soft loan, which is:

$$
\operatorname{Prob}\left[P R_{i}=1 \mid \text { Soft }_{i}=1, \operatorname{Loan}_{i}=1\right]=\frac{\Phi_{2}\left(\alpha+V_{i} \delta, Z_{i} \gamma, \rho_{\nu \eta}\right)}{\Phi\left(Z_{i} \gamma\right)}
$$

The second is the probability of changing supplier should the current supplier increase its price given that the firm has a "hard" loan, which is:

$$
\operatorname{Prob}\left[P R_{i}=1 \mid \text { Soft }_{i}=0, \operatorname{Loan}_{i}=1\right]=\frac{\Phi_{2}\left(V_{i} \delta, Z_{i} \gamma, \rho_{\nu \eta}\right)}{\Phi\left(Z_{i} \gamma\right)}
$$

The difference in price responsiveness between those that have a soft loan and those that have a hard loan is then:

$$
\operatorname{Prob}\left[P R_{i} \mid \operatorname{Soft}_{i}=1, \operatorname{Loan}_{i}=1\right]-\operatorname{Prob}\left[P R_{i} \mid \operatorname{Soft}_{i}=0, \operatorname{Loan}_{i}=1\right]
$$

Before presenting the results (in Table 6), it is important to discuss some important control variables that might determine $P R$. The fact that a firm will (or will not) change its main supplier in equation (9) is not only due to the manager's expectation of a soft loan. First, the firm might change supplier if and only if it has an alternative. Fortunately, BEEPS allows us to control for the number of suppliers of the firm's main material input (none, 1-3, or 4 or more). Second, a firm is more likely to change supplier if it has ever had problems with its 
current supplier. We control for the percentage of sales in 2001 which were lost due to delivery delays from material input suppliers, as well as a dummy variable that equals one if the firm has ever had to resolve an overdue payment. Lastly, we include a dummy variable for the firm being a member of a business association. By doing so, we take into account the argument of Johnson et al. (2002, p.223), whereby firms have more information about suppliers with whom they deal and are therefore willing to pay more to an incumbent supplier than to one with whom they have never worked. However, Johnson et al. (2002) also argue that members of an association are more likely to abandon their incumbent supplier because the association might provide information about the reliability of potential suppliers 20 All of the regressions reported in Table 6 also include the variables used in the previous section. A list of the controls whose effects are not presented in the columns is shown in the notes to Table 6. Similarly, we provide a list of the variables included in the selection equation (10) (Notes iii., iv. and v.).

\section{-Insert Table [6] about here-}

Column $[\mathrm{A}]$ contains the basic specification estimated with the sample including only loan applicants. Columns $[\mathrm{B}]-[\mathrm{F}]$ modify the control variables. Column $[\mathrm{G}]$ is estimated with the BEEPS II sample. These alternative specifications produce results that are very similar to those in column $[\mathrm{A}]$. Firms that report themselves as having a soft loan are 4.7-5.2 percentage points less likely to change supplier if the existing supplier increases its price by 10 percent.

\section{Conclusion}

This empirical paper has considered that the SBC syndrome occurs when a bank cannot commit an enterprise to hold to a fixed initial budget and/or the timing of repayment. Five results appear robust. First, managers' expectations of having a soft loan are lower when

\footnotetext{
${ }^{20}$ We also checked that the results in Tables 3 and 4 did not change when we added these control variables in both the Loan and the Soft equations. These results, available upon request, are broadly the same as those presented in Section 4
} 
the initial financing requires collateral. Second, the probability of having a loan application accepted as well as of expecting an extension in case of trouble are higher for larger firms. The third conclusion might seem surprising: State firms have a lower probability of having a loan application accepted. Furthermore, they are no more likely than foreign firms to expect an extension in case of trouble, except in CIS countries. Fourth, firms owned by employees and managers in CIS countries are more likely to anticipate an extension if they fall behind in their bank repayments. Finally, managers of firms which were in financial distress in the recent past are more likely to believe that the bank will not engage in legal proceedings to take possession of assets if they fall behind in their bank repayments, especially in the CIS.

We conclude with two words of caution. First, concerning the non-impact of bank ownership on expectations of soft loans, our results are no more than suggestive because we do not really know whether the main financing source is the bank which grants the loan. The second issue is whether or not our variable Soft really measures soft budgets, resulting in inefficient enterprise decisions. We provide some results that suggest that it does: if a manager believes his firm will obtain an extension of the loan in case of trouble, he also answers that he will purchase his main material input from his existing main supplier, even if the latter increases its supply price. So he says that he will be less price responsive. However, the validity of survey evidence concerning potential behaviors rather than facts might be questioned. In order to test whether soft budgets lead to efficiency losses, we would require a true time-series dimension. This remark highlights that we need more surveys specifically designed to study the determinants of the SBC phenomenon and how the behavior of firms is distorted by anticipations. This will likely open a wide field for further research. 
Anderson, J. H., Korsun, G. and Murrell, P. (2000), "Which enterprises (believe they) have soft budgets? Evidence on the effects of ownership and decentralization in Mongolia", Journal of Comparative Economics, vol. 28: pp. 219-46.

Berglof, E. and Bolton, P. (2002), "The great divide and beyond: financial architecture in transition", Journal of Economic Perspectives, vol. 16: pp. 77-100.

Berglof, E. and Roland, G. (1998), "Soft budget constraints and banking in transition economies", Journal of Comparative Economics, vol. 26: pp. 18-40.

Bertero, E. and Rondi, L. (2000), "Financial pressure and the behaviour of public enterprises under soft and hard budget constraints: evidence from Italian panel data", Journal of Public Economics, vol. 75: pp. 73-98.

Bonin, J. and Schaffer, M. (1995), "Banks, firms, bad debts and bankruptcy in Hungary 1991-4", CEP Discussion Papers 0234, Centre for Economic Performance, LSE.

Boycko, M., Shleifer, A. and Vishny, R. W. (1996), "A theory of privatization", Economic Journal, vol. 106: pp. 309-19.

Boyes, W. J., Hoffman, D. L. and Low, S. A. (1989), "An econometric analysis of the bank credit scoring problem", Journal of Econometrics, vol. 40: pp. 3-14.

Cappellari, L. and Jenkins, S. P. (2006), "Calculation of multivariate normal probabilities by simulation, with applications to maximum simulated likelihood estimation", Stata Journal, vol. 6: pp. 156-89.

Coricelli, F. and Djankov, S. (2001), "Hardened budgets and enterprise restructuring: 
theory and an application to Romania", Journal of Comparative Economics, vol. 29: pp. 749-63.

Dewatripont, M. and Maskin, E. S. (1995), "Credit and efficiency in centralized and decentralized economies", Review of Economic Studies, vol. 62: pp. 541-55.

Dewatripont, M. and Roland, G. (2000), "Soft budget constraints, transition and financial systems", Journal of Institutional and Theoretical Economics, vol. 156: pp. 245-60.

Djankov, S. and Murrell, P. (2002), "Enterprise restructuring in transition: a quantitative survey", Journal of Economic Literature, vol. 40: pp. 739-92.

Gouriéroux, C. and Monfort, A. (1995), Simulation based econometric methods, CORE Lectures Series, Oxford University Press.

Greene, W. H. (1992), "A statistical model for credit scoring”, Working Papers 92-29, New York University, Leonard N. Stern School of Business, Department of Economics.

Greene, W. H. (1998), "Sample selection in credit-scoring models", Japan and the World Economy, vol. 10: pp. 299-316.

Greene, W. H. (2003), Econometric Analysis, Prentice Hall, fifth edition.

Hajivassiliou, V., McFadden, D. and Ruud, P. (1996), "Simulation of multivariate normal rectangle probabilities and their derivatives: theoretical and computational results", Journal of Econometrics, vol. 72: pp. 85-134.

Hellman, J. and Kaufmann, D. (2002), "The Inequality of influence", Working paper, Social Science Research Network, http://ssrn.com/abstract=386901.

HuAng, H. and Xu, C. (1999), "Financial institutions and the financial crisis in East Asia", European Economic Review, vol. 43: pp. 903-14. 
Huang, H., Marin, D. and Xu, C. (2004), "Financial crisis, economic recovery, and banking development in Russia, and other FSU countries", Discussion Papers 79, Humboldt University of Berlin.

Johnson, S., McMillan, J. and Woodruff, C. (2002), "Courts and relational contracts", Journal of Law, Economics and Organization, vol. 18: pp. 221-77.

Kornai, J. (1979), "Resource-constrained versus demand-constrained systems", Econometrica, vol. 47: pp. 801-20.

KornAI, J. (1998), "Legal obligation, non-compliance and soft budget constraint", in NEWMan, P. (editor), The New Palgrave: Dictionary of Economics and the Law, Macmillan, London, pp. 533-39.

Kornai, J. (2000), “Ten years after 'The Road to a Free Economy': the author's self evaluation", in Pleskovic, B. and Stern, N. (editors), Annual World Bank Conference on Development Economics, World Bank, Washington, pp. 49-66.

KornAI, J. (2001), "Hardening the budget constraint: the experience of the post-socialist countries", European Economic Review, vol. 45: pp. 1573-99.

Kornai, J., Maskin, E. S. and Roland, G. (2003), "Understanding the budget constraint", Journal of Economic Literature, vol. 41: pp. 1095-1136.

Li, D. D. and LiAng, M. (1998), "Causes of the soft budget constraint: evidence on three explanations", Journal of Comparative Economics, vol. 26: pp. 104-16.

MemRB Custom Research Worldwide (2002), "The Business Environment and Enterprise Performance Survey-2002: a brief report on observations, experiences and methodology from the survey EBRD-World Bank Business Environment and Enterprise Performance Survey II.", Technical report, http://www.ebrd.com/pubs/econo/beepsr02.pdf. 
Qian, Y. and Roland, G. (1998), "Federalism and the soft budget constraint", American Economic Review, vol. 88: pp. 1143-62.

Schaffer, M. E. (1998), "Do firms in transition economies have soft budget constraints? A reconsideration of concepts and evidence", Journal of Comparative Economics, vol. 26: pp. $80-103$.

SEGAL, I. (1998), "Monopoly and soft budget constraint", Rand Journal of Economics, vol. 29: pp. 596-609.

VAn De Ven, W. P. M. M. and Van PraAg, B. M. S. (1981), "The demand for deductibles in private health insurance : a probit model with sample selection", Journal of Econometrics, vol. 17: pp. 229-52. 
Table 1: Descriptive statistics of the main variables of the sample

\begin{tabular}{|c|c|c|c|c|c|c|c|c|c|c|c|}
\hline \multirow[b]{2}{*}{ Firm characteristics } & \multicolumn{3}{|c|}{ BEEPS II sample } & \multicolumn{3}{|c|}{ Original sample } & \multicolumn{3}{|c|}{ Estimation sample } & \multirow[b]{2}{*}{ Min } & \multirow[b]{2}{*}{ Max } \\
\hline & Obs & Mean & Std. dev. & Obs & Mean & Std. dev. & Obs & Mean & Std. dev. & & \\
\hline The firm recently obtained a loan & 5846 & 0.405 & 0.491 & 4621 & 0.512 & 0.499 & 3531 & 0.489 & 0.499 & 0 & 1 \\
\hline $\begin{array}{l}\text { Unprofitable in } 2001 \\
\text { Largest shareholder }\end{array}$ & 5534 & 0.057 & 0.233 & 4388 & 0.061 & 0.239 & 3531 & 0.060 & 0.238 & 0 & 1 \\
\hline $\begin{array}{l}\text { Largest shareholder } \\
\text { Individual }\end{array}$ & 5856 & 0.506 & 0.500 & 4631 & & 0.499 & & & & & \\
\hline Family & 5856 & 0.062 & 0.241 & $\begin{array}{l}4031 \\
4631\end{array}$ & $\begin{array}{l}0.514 \\
0.065\end{array}$ & $\begin{array}{l}0.499 \\
0.248\end{array}$ & $\begin{array}{l}3531 \\
3531\end{array}$ & 0.510 & 0.499 & 0 & 1 \\
\hline Domestic company & 5856 & 0.068 & 0.252 & 4631 & 0.073 & $\begin{array}{l}0.240 \\
0.259\end{array}$ & 3531 & 0.073 & 0.260 & 0 & $\begin{array}{l}1 \\
1\end{array}$ \\
\hline Foreign company & 5856 & 0.101 & 0.302 & 4631 & 0.095 & 0.294 & 3531 & 0.096 & 0.295 & 0 & 1 \\
\hline Manager of the firm & 5856 & 0.029 & 0.169 & 4631 & 0.030 & 0.172 & 3531 & 0.029 & 0.169 & 0 & 1 \\
\hline Employees of the firm & 5856 & 0.035 & 0.185 & 4631 & 0.036 & 0.186 & 3531 & 0.037 & 0.189 & 0 & 1 \\
\hline Government & 5856 & 0.135 & 0.342 & 4631 & 0.123 & 0.329 & 3531 & 0.128 & 0.334 & 0 & 1 \\
\hline Others & 5856 & 0.062 & 0.241 & 4631 & 0.060 & 0.238 & 3531 & 0.058 & 0.232 & 0 & 1 \\
\hline Firm size & & & & & & & & & & & \\
\hline Less than 49 employees & 5856 & 0.680 & 0.467 & 4631 & 0.669 & 0.470 & 3531 & 0.664 & 0.472 & 0 & 1 \\
\hline Between 50 - 249 employees & 5856 & 0.183 & 0.386 & 4631 & 0.186 & 0.389 & 3531 & 0.186 & 0.389 & 0 & 1 \\
\hline $\begin{array}{l}\text { More than } 250 \text { employees } \\
\text { Number of competitors }\end{array}$ & 5856 & 0.137 & 0.344 & 4631 & 0.144 & 0.351 & 3531 & 0.149 & 0.356 & 0 & 1 \\
\hline Monopoly & 5742 & 0.013 & 0.115 & 4542 & 0.013 & 0.113 & 3531 & 0.013 & 0.113 & 0 & 1 \\
\hline $1-3$ competitors & 5742 & 0.168 & 0.374 & 4542 & 0.163 & 0.369 & 3531 & 0.166 & 0.372 & 0 & 1 \\
\hline $\begin{array}{l}4 \text { or more competitors } \\
\text { Customers }\end{array}$ & 5742 & 0.819 & 0.385 & 4542 & 0.823 & 0.380 & 3531 & 0.820 & 0.383 & 0 & 1 \\
\hline Sales to government & 5856 & 10.683 & 24.462 & 4631 & 10.269 & 23.68 & 3531 & 10.820 & 24.37 & 0 & 100 \\
\hline Sales to multinational firmss & 5856 & 4.021 & 14.118 & 4631 & 4.024 & 13.77 & 3531 & 4.18 & 14.14 & 0 & 100 \\
\hline Manager characteristics & & & & & & & & & & & 1 \\
\hline $\begin{array}{l}\text { Expect to be bailed out by the bank } \\
\text { Loan characteristics }\end{array}$ & 2025 & 0.412 & 0.492 & 2025 & 0.412 & 0.492 & 1676 & 0.405 & 0.490 & 0 & 1 \\
\hline $\begin{array}{l}\text { Collateral } \\
\text { Financing Source }\end{array}$ & 2368 & 0.806 & 0.395 & 2368 & 0.806 & 0.385 & 1676 & 0.815 & 0.378 & 0 & 1 \\
\hline Local private bank & 5856 & 0.079 & 0.270 & 4631 & 0.100 & 0.300 & 3531 & 0.096 & 0.293 & 0 & 1 \\
\hline State bank & 5856 & 0.045 & 0.206 & 4631 & 0.056 & 0.230 & 3531 & 0.052 & 0.221 & 0 & 1 \\
\hline Foreign bank & 5856 & 0.019 & 0.138 & 4631 & 0.024 & 0.154 & 3531 & 0.024 & 0.153 & 0 & 1 \\
\hline$>$ From family and friends & 5856 & 0.068 & 0.253 & 4631 & 0.073 & 0.260 & 3531 & 0.070 & 0.255 & 0 & 1 \\
\hline Government & 5856 & 0.020 & 0.141 & 4631 & 0.017 & 0.130 & 3531 & 0.015 & 0.121 & 0 & 1 \\
\hline Exclusion variables & & & & & & & & & & & \\
\hline External auditor & 5703 & 0.497 & 0.500 & 4513 & 0.491 & 0.499 & 3531 & 0.491 & 0.499 & 0 & 1 \\
\hline International accounting standards & 5371 & 0.405 & 0.491 & 4237 & 0.397 & 0.489 & 3531 & 0.385 & 0.486 & 0 & 1 \\
\hline Training & 5797 & 0.512 & 0.500 & 4584 & 0.525 & 0.499 & 3531 & 0.525 & 0.499 & 0 & 1 \\
\hline
\end{tabular}

ii. The original sample includes all of the firms in the BEEPS II sample that are assumed to be loan applicants. (Original sample = BEEPS II sample minus firms that are not loan applicants.)

iii. The estimation sample includes all of the firms in the original sample, other than those which have missing values for the variables in our baseline model (estimated in Table 3. 
Table 2: Enterprise managers were asked the following question: If your firm were to fall behind in its bank repayments, which of the following would best describe how you would expect the bank to react?

\begin{tabular}{|c|c|c|c|c|}
\hline & \multicolumn{2}{|c|}{ Original sample } & \multicolumn{2}{|c|}{ Estimation sample } \\
\hline & Number & Percent & Number & Percent \\
\hline [1] Do nothing & 106 & 5.23 & 84 & 5.01 \\
\hline [2] Extend the term of the loan without changing the conditions & 729 & 36.00 & 593 & 35.42 \\
\hline 3] Extend the term of the loan but increase the interest rate & 800 & 39.51 & 663 & 39.54 \\
\hline [4] Begin legal proceedings to take possession of assets & 390 & 19.26 & 336 & 20.03 \\
\hline Total & 2025 & 100.00 & 1676 & 100 \\
\hline
\end{tabular}


Table 3: Bivariate censored probit estimates

\begin{tabular}{|c|c|c|c|c|c|}
\hline \multirow{3}{*}{$\begin{array}{l}\text { Firm characteristics } \\
\text { Main shareholder }\end{array}$} & \multicolumn{2}{|c|}{ Soft } & & \multicolumn{2}{|c|}{ Loan } \\
\hline & \multirow[t]{2}{*}{ Coef. } & \multicolumn{2}{|l|}{ (Std. error) } & \multirow[t]{2}{*}{ Coef. } & (Std. error) \\
\hline & & & & & \\
\hline Individual & 0.065 & $(0.094)$ & & $0.071^{* *}$ & $(0.034)$ \\
\hline Family & -0.136 & $(0.174)$ & & $0.231^{* * *}$ & $(0.065)$ \\
\hline Domestic company & -0.141 & $(0.175)$ & & $0.392^{* * *}$ & $(0.059)$ \\
\hline Foreign company & \multicolumn{2}{|c|}{ Omitted Category } & & \multicolumn{2}{|c|}{ Omitted Category } \\
\hline Managers & 0.165 & $(0.221)$ & & -0.0123 & $(0.096)$ \\
\hline Employees & 0.204 & $(0.193)$ & & $0.204^{* * *}$ & $(0.063)$ \\
\hline Government & 0.117 & $(0.116)$ & & $-0.133^{* *}$ & $(0.057)$ \\
\hline Others & 0.120 & $(0.120)$ & & 0.0162 & $(0.059)$ \\
\hline Firm size & & & & & \\
\hline Employees $<50$ & -0.104 & $(0.275)$ & & $-0.487 * * *$ & $(0.037)$ \\
\hline $50 \leq$ Employees $<250$ & \multicolumn{2}{|c|}{ Omitted Category } & & \multicolumn{2}{|c|}{ Omitted Category } \\
\hline $\begin{array}{l}\text { Employees } \geq 250 \\
\text { Number of competitors }\end{array}$ & -0.088 & $(0.101)$ & & $0.230 * * *$ & $(0.033)$ \\
\hline Monopoly & -0.280 & $(0.322)$ & & $-0.124^{*}$ & $(0.065)$ \\
\hline $1-3$ competitors & \multicolumn{2}{|c|}{ Omitted Category } & & \multicolumn{2}{|c|}{ Omitted Category } \\
\hline $\begin{array}{l}4 \text { or more competitors } \\
\text { Customers }\end{array}$ & 0.045 & $(0.088)$ & & $-0.085^{* *}$ & $(0.038)$ \\
\hline Sales to government & -0.227 & $(0.186)$ & & -0.062 & $(0.064)$ \\
\hline Sales to multinational firms & -0.316 & $(0.263)$ & & $0.244^{* * *}$ & $(0.091)$ \\
\hline Unprofitable in 2001 & 0.226 & $(0.160)$ & & $-0.112^{*}$ & $(0.061)$ \\
\hline Loan characteristics & & & & & \\
\hline Collateral & $-0.205^{* *}$ & $(0.090)$ & & & \\
\hline Financing source & & & & & \\
\hline Local private bank & 0.0950 & $(0.067)$ & & & \\
\hline State bank & 0.00591 & $(0.114)$ & & & \\
\hline Foreign bank & 0.0731 & $(0.175)$ & & & \\
\hline$>$ From family and friends & -0.132 & $(0.161)$ & & & \\
\hline Government & -0.196 & $(0.327)$ & & & \\
\hline External audit & & & & $0.153^{* * *}$ & $(0.041)$ \\
\hline IAS & & & & $0.0780 * *$ & $(0.033)$ \\
\hline Training & & & & $0.238^{* * *}$ & $(0.023)$ \\
\hline Manager education dummies & Yes & & & Yes & \\
\hline Manager age dummies & Yes & & & Yes & \\
\hline Sector dummies & Yes & & & Yes & \\
\hline Country dummies & Yes & & & Yes & \\
\hline$\rho_{\epsilon \eta}$ (std. error) & & & -0.413 & $(0.541)$ & \\
\hline Wald test & & & 0.582 & & \\
\hline Obs. censored & & & 1855 & & \\
\hline Obs. & & & 3531 & & \\
\hline Log likelihood & & & -3068.40 & & \\
\hline
\end{tabular}

Notes: i. $\dagger, *, * *$ and $* * *$ represent $15,10,5$ and $1 \%$ significance, respectively.

ii. Standard errors clustered at the country level are in parentheses. 
Table 4: Marginal effects of the bivariate probit with censoring

\begin{tabular}{|c|c|c|}
\hline & $\frac{d \text { Prob }[\text { Loan }=1]}{d Z}$ & $\frac{d \operatorname{Prob}[\text { Soft }=1 \mid \operatorname{Loan}=1]}{d X 1}$ \\
\hline \multicolumn{3}{|l|}{ Main shareholder } \\
\hline Individual & $\begin{array}{c}0.028^{* *} \\
(0.013)\end{array}$ & $\begin{array}{c}0.034 \\
(0.033)\end{array}$ \\
\hline Family & $\begin{array}{c}0.091^{* * *} \\
(0.025)\end{array}$ & $\begin{array}{l}-0.029 \\
(0.062)\end{array}$ \\
\hline Domestic company & $\begin{array}{c}0.154^{* * *} \\
(0.022)\end{array}$ & $\begin{array}{l}-0.015 \\
(0.042)\end{array}$ \\
\hline Foreign company & \multicolumn{2}{|c|}{ Omitted Category } \\
\hline Managers & $\begin{array}{l}-0.004 \\
(0.038)\end{array}$ & $\begin{array}{c}0.066 \\
(0.090)\end{array}$ \\
\hline Employees & $\begin{array}{c}0.081^{* * *} \\
(0.024)\end{array}$ & $\begin{array}{l}0.106 \\
(0.082)\end{array}$ \\
\hline State & $\begin{array}{c}-0.052^{* *} \\
(0.022)\end{array}$ & $\begin{array}{c}0.032 \\
(0.075)\end{array}$ \\
\hline Others & $\begin{array}{c}0.006 \\
(0.023)\end{array}$ & $\begin{array}{c}0.051 \\
(0.051)\end{array}$ \\
\hline Firm size & & \\
\hline Employees $<50$ & $\begin{array}{c}-0.192^{* * *} \\
(0.014)\end{array}$ & $\begin{array}{c}-0.095^{* * *} \\
(0.035)\end{array}$ \\
\hline $50 \leq$ Employees $<250$ & \multicolumn{2}{|c|}{ Omitted Category } \\
\hline Employees $\geq 250$ & $\begin{array}{c}0.091^{* * * *} \\
(0.013)\end{array}$ & $\begin{array}{l}-0.010 \\
(0.035)\end{array}$ \\
\hline Number of competit & & \\
\hline Monopoly & $\begin{array}{l}-0.049^{*} \\
(0.025)\end{array}$ & $\begin{array}{c}-0.117 \\
(0.103)\end{array}$ \\
\hline 1-3 competitors & \multicolumn{2}{|c|}{ Omitted Category } \\
\hline 4 or more competitors & $\begin{array}{c}-0.033^{* *} \\
(0.015)\end{array}$ & $\begin{array}{c}0.009 \\
(0.031)\end{array}$ \\
\hline Loan characteristics & & \\
\hline Collateral & & $\begin{array}{c}-0.082^{* * *} \\
(0.030)\end{array}$ \\
\hline Unprofitable in 2001 & $\begin{array}{l}-0.044^{*} \\
(0.024)\end{array}$ & $\begin{array}{c}0.079 \\
(0.065)\end{array}$ \\
\hline$\rho_{\epsilon \eta}$ (std. error) & \multicolumn{2}{|c|}{$-0.413(0.541)$} \\
\hline Wald test & \multicolumn{2}{|c|}{0.582} \\
\hline Obs. censored & \multicolumn{2}{|r|}{1855} \\
\hline Obs. & \multicolumn{2}{|r|}{3531} \\
\hline
\end{tabular}


Table 5: Marginal effects in the BEEPS II sample

\begin{tabular}{|c|c|c|c|c|c|c|}
\hline \multirow{2}{*}{ Main shareholder } & \multicolumn{2}{|c|}{ Total BEEPS II sample } & \multicolumn{2}{|c|}{ CIS countries } & \multicolumn{2}{|c|}{ Non-CIS countries } \\
\hline & $\frac{d \operatorname{Pr}[\text { Loan }=1]}{d Z}$ & $\frac{d \operatorname{Pr}[\text { Soft }=1 \mid \text { Loan }=1]}{d X 1}$ & $\frac{d \operatorname{Pr}[\operatorname{Loan}=1]}{d Z}$ & $\frac{S o f t=1 \mid \operatorname{Loan}=1]}{d X 1}$ & $\frac{d \operatorname{Pr}[\operatorname{Loan}=1]}{d Z}$ & $\frac{d \operatorname{Pr}[\text { Soft }=1 \mid \text { Loan }=1]}{d X 1}$ \\
\hline Individual & $\begin{array}{c}0.055^{* * *} \\
(0.014)\end{array}$ & $\begin{array}{c}0.035 \\
(0.033)\end{array}$ & $\begin{array}{l}0.0209 \\
(0.016)\end{array}$ & $\begin{array}{l}0.069^{*} \\
(0.036)\end{array}$ & $\begin{array}{c}0.090^{* * * *} \\
(0.018)\end{array}$ & $\begin{array}{l}-0.005 \\
(0.038)\end{array}$ \\
\hline Family & $\begin{array}{c}0.124^{* * *} \\
(0.026)\end{array}$ & $\begin{array}{l}-0.029 \\
(0.062)\end{array}$ & $\begin{array}{c}0.043 \\
(0.039)\end{array}$ & $\begin{array}{l}-0.011 \\
(0.104)\end{array}$ & $\begin{array}{c}0.169 * * * \\
(0.029)\end{array}$ & $\begin{array}{l}-0.074 \\
(0.071)\end{array}$ \\
\hline Domestic company & $\begin{array}{c}0.152^{* * *} \\
(0.020)\end{array}$ & $\begin{array}{l}-0.013 \\
(0.042)\end{array}$ & $\begin{array}{c}0.132^{* * *} \\
(0.030)\end{array}$ & $\begin{array}{l}0.0199 \\
(0.040)\end{array}$ & $\begin{array}{c}0.169 * * * \\
(0.024)\end{array}$ & $\begin{array}{l}-0.027 \\
(0.055)\end{array}$ \\
\hline Foreign company & \multicolumn{2}{|c|}{ Omitted Category } & \multicolumn{2}{|c|}{ Omitted Category } & \multicolumn{2}{|c|}{ Omitted Category } \\
\hline Managers & $\begin{array}{c}0.038 \\
(0.034)\end{array}$ & $\begin{array}{c}0.069 \\
(0.089)\end{array}$ & $\begin{array}{c}0.067^{* *} \\
(0.034)\end{array}$ & $\begin{array}{c}0.215^{* * *} \\
(0.081)\end{array}$ & $\begin{array}{l}0.0008 \\
(0.048)\end{array}$ & $\begin{array}{c}-0.058 \\
(0.141)\end{array}$ \\
\hline Employees & $\begin{array}{c}0.090^{* * *} \\
(0.025)\end{array}$ & $\begin{array}{c}0.110 \\
(0.080)\end{array}$ & $\begin{array}{c}0.089^{* *} \\
(0.042)\end{array}$ & $\begin{array}{c}0.212^{* *} \\
(0.090)\end{array}$ & $\begin{array}{c}0.053 \\
(0.037)\end{array}$ & $\begin{array}{l}-0.005 \\
(0.140)\end{array}$ \\
\hline State & $\begin{array}{c}-0.059^{* * *} \\
(0.020)\end{array}$ & $\begin{array}{c}0.032 \\
(0.074)\end{array}$ & $\begin{array}{c}-0.056^{* *} \\
(0.026)\end{array}$ & $\begin{array}{c}0.119 \\
(0.097)\end{array}$ & $\begin{array}{c}-0.072^{* * *} \\
(0.027)\end{array}$ & $\begin{array}{l}-0.033 \\
(0.078)\end{array}$ \\
\hline Others & $\begin{array}{c}0.012 \\
(0.024)\end{array}$ & $\begin{array}{c}0.052 \\
(0.049)\end{array}$ & $\begin{array}{l}-0.018 \\
(0.032)\end{array}$ & $\begin{array}{c}0.180^{* *} \\
(0.073)\end{array}$ & $\begin{array}{c}0.044 \\
(0.033)\end{array}$ & $\begin{array}{l}-0.007 \\
(0.041)\end{array}$ \\
\hline \multicolumn{7}{|l|}{ Firm size } \\
\hline Employees $<50$ & $\begin{array}{c}-0.175^{* * *} \\
(0.016)\end{array}$ & $\begin{array}{c}-0.092^{* * *} \\
(0.034)\end{array}$ & $\begin{array}{c}-0.187^{* * *} \\
(0.028)\end{array}$ & $\begin{array}{c}-0.133^{* * *} \\
(0.036)\end{array}$ & $\begin{array}{c}-0.175^{* * * *} \\
(0.018)\end{array}$ & $\begin{array}{c}-0.099^{*} \\
(0.051)\end{array}$ \\
\hline $50 \leq$ Employees $<250$ & \multicolumn{2}{|c|}{ Omitted Category } & \multicolumn{2}{|c|}{ Omitted Category } & \multicolumn{2}{|c|}{ Omitted Category } \\
\hline Employees $\geq 250$ & $\begin{array}{c}0.089^{* * *} \\
(0.011)\end{array}$ & $\begin{array}{c}-0.011 \\
(0.035)\end{array}$ & $\begin{array}{c}0.043^{* * *} \\
(0.015)\end{array}$ & $\begin{array}{l}-0.013 \\
(0.066)\end{array}$ & $\begin{array}{c}0.141^{* * *} \\
(0.015)\end{array}$ & $\begin{array}{l}-0.010 \\
(0.035)\end{array}$ \\
\hline \multicolumn{7}{|c|}{ Number of competitors } \\
\hline Monopoly & $\begin{array}{l}-0.004 \\
(0.024)\end{array}$ & $\begin{array}{l}-0.119 \\
(0.104)\end{array}$ & $\begin{array}{c}0.039^{* *} \\
(0.018)\end{array}$ & $\begin{array}{c}-0.098 \\
(0.167)\end{array}$ & $\begin{array}{l}-0.081^{\dagger} \\
(0.054)\end{array}$ & $\begin{array}{c}-0.142 \\
(0.144)\end{array}$ \\
\hline 1-3 competitors & \multicolumn{2}{|c|}{ Omitted Category } & \multicolumn{2}{|c|}{ Omitted Category } & \multicolumn{2}{|c|}{ Omitted Category } \\
\hline 4 or more competitors & $\begin{array}{l}-0.013 \\
(0.015)\end{array}$ & $\begin{array}{c}0.010 \\
(0.031)\end{array}$ & $\begin{array}{l}-0.021 \\
(0.022)\end{array}$ & $\begin{array}{c}0.046 \\
(0.047)\end{array}$ & $\begin{array}{l}-0.004 \\
(0.017)\end{array}$ & $\begin{array}{l}-0.030 \\
(0.043)\end{array}$ \\
\hline \multicolumn{7}{|l|}{ Loan characteristics } \\
\hline Collateral & & $\begin{array}{c}-0.082^{* * *} \\
(0.031)\end{array}$ & & $\begin{array}{c}-0.126^{* *} \\
(0.062)\end{array}$ & & $\begin{array}{c}-0.071^{* * *} \\
(0.026)\end{array}$ \\
\hline Unprofitable in 2001 & $\begin{array}{c}0.019 \\
(0.022)\end{array}$ & $\begin{array}{c}0.086 \\
(0.062)\end{array}$ & $\begin{array}{c}0.017 \\
(0.040)\end{array}$ & $\begin{array}{c}0.233^{* *} \\
(0.11)\end{array}$ & $\begin{array}{c}0.016 \\
(0.018)\end{array}$ & $\begin{array}{c}0.038 \\
(0.068)\end{array}$ \\
\hline$\rho_{\epsilon \vartheta}($ std. error $)$ & \multicolumn{2}{|c|}{$-0.56(0.452)$} & \multicolumn{2}{|c|}{$-0.839^{* * *}(0.266)$} & \multicolumn{2}{|c|}{$-0.018(0.782)$} \\
\hline Wald test & \multicolumn{2}{|c|}{1.562} & \multirow{2}{*}{\multicolumn{2}{|c|}{$\begin{array}{l}9.948 \\
2265\end{array}$}} & \multicolumn{2}{|c|}{0.000} \\
\hline Obs. & \multicolumn{2}{|r|}{4537} & \multirow{2}{*}{\multicolumn{2}{|c|}{2265}} & \multicolumn{2}{|r|}{2298} \\
\hline Censored obs. & \multicolumn{2}{|r|}{2861} & & & \multicolumn{2}{|r|}{1311} \\
\hline
\end{tabular}

ii. Standard errors clustered at the country level are in parentheses.

iii. The variables included in the Loan and Soft equations are the same as those included in the Loan and Soft equations of the bivariate probit with censoring presented in Table 3 
Table 6: Is a firm with a soft loan less likely to change main supplier if their supply price rises by $10 \%$ ?

$\operatorname{Prob}\left[\operatorname{PR}_{i} \mid\right.$ Soft $\left._{i}=1, \operatorname{Loan}_{i}=1\right]-\operatorname{Prob}\left[P R_{i} \mid\right.$ Soft $\left._{i}=0, \operatorname{Loan}_{i}=1\right]$

\begin{tabular}{|c|c|c|c|c|c|c|c|}
\hline \multirow[b]{2}{*}{ Soft } & {$[\mathrm{A}]$} & [B] & {$[\mathrm{C}]$} & [D] & {$[\mathrm{E}]$} & {$[\mathrm{F}]$} & {$[\mathrm{G}]$} \\
\hline & $\begin{array}{l}-0.052^{*} \\
(0.031)\end{array}$ & $\begin{array}{l}-0.047^{\dagger} \\
(0.030)\end{array}$ & $\begin{array}{l}-0.052^{*} \\
(0.031)\end{array}$ & $\begin{array}{l}-0.050^{\dagger} \\
(0.031)\end{array}$ & $\begin{array}{l}-0.049^{\dagger} \\
(0.031)\end{array}$ & $\begin{array}{l}-0.052^{*} \\
(0.031)\end{array}$ & $\begin{array}{l}-0.051 \dagger \\
(0.031)\end{array}$ \\
\hline \multicolumn{8}{|c|}{$\begin{array}{l}\text { Number of suppliers of } \\
\text { the firm's main material input }\end{array}$} \\
\hline None & $\begin{array}{l}-0.003 \\
(0.087)\end{array}$ & $\begin{array}{c}0.012 \\
(0.082)\end{array}$ & $\begin{array}{l}-0.002 \\
(0.088)\end{array}$ & $\begin{array}{l}-0.022 \\
(0.089)\end{array}$ & $\begin{array}{l}-0.001 \\
(0.086)\end{array}$ & $\begin{array}{l}0.0009 \\
(0.088)\end{array}$ & $\begin{array}{l}-0.002 \\
(0.086)\end{array}$ \\
\hline 1-3 suppliers & $\begin{array}{c}-0.208^{* * *} \\
(0.028)\end{array}$ & $\begin{array}{c}-0.216^{* * * *} \\
(0.027)\end{array}$ & $\begin{array}{c}-0.209^{* * *} \\
(0.028)\end{array}$ & $\begin{array}{c}-0.212^{* * *} \\
(0.029)\end{array}$ & $\begin{array}{l}-0.211^{* * *} \\
(0.028)\end{array}$ & $\begin{array}{l}-0.210^{* * *} \\
(0.029)\end{array}$ & $\begin{array}{c}-0.210^{* * *} \\
(0.029)\end{array}$ \\
\hline 4 or more suppliers & & & & Omitted Categc & & & \\
\hline \multicolumn{8}{|c|}{ Percent of sales in 2001 lost due to delivery delays from } \\
\hline material input suppliers & $\begin{array}{l}-0.352 \\
(0.274)\end{array}$ & & $\begin{array}{l}-0.349 \\
(0.273)\end{array}$ & $\begin{array}{l}-0.302 \\
(0.276)\end{array}$ & $\begin{array}{l}-0.294 \\
(0.266)\end{array}$ & $\begin{array}{l}-0.358 \\
(0.274)\end{array}$ & $\begin{array}{l}-0.358 \\
(0.275)\end{array}$ \\
\hline Business Association & $\begin{array}{l}-0.013 \\
(0.028)\end{array}$ & $\begin{array}{l}-0.009 \\
(0.028)\end{array}$ & & $\begin{array}{r}-0.0075 \\
(0.028)\end{array}$ & $\begin{array}{l}-0.015 \\
(0.027)\end{array}$ & $\begin{array}{l}-0.014 \\
(0.028)\end{array}$ & $\begin{array}{l}-0.013 \\
(0.028)\end{array}$ \\
\hline Overdue payment & $\begin{array}{c}0.088^{* * *} \\
(0.032)\end{array}$ & $\begin{array}{c}0.085^{* * *} \\
(0.033)\end{array}$ & $\begin{array}{c}0.087^{* * *} \\
(0.032)\end{array}$ & & $\begin{array}{c}0.085^{* * *} \\
(0.030)\end{array}$ & $\begin{array}{c}0.085^{* * *} * \\
(0.031)\end{array}$ & $\begin{array}{c}0.089^{* * *} * \\
(0.033)\end{array}$ \\
\hline \multicolumn{8}{|l|}{ Main shareholder } \\
\hline Individual & $\begin{array}{c}0.107^{* *} \\
(0.054)\end{array}$ & $\begin{array}{c}0.108^{* *} \\
(0.054)\end{array}$ & $\begin{array}{c}0.108^{* *} \\
(0.054)\end{array}$ & $\begin{array}{l}0.104^{*} \\
(0.054)\end{array}$ & & $\begin{array}{c}0.106^{* *} \\
(0.054)\end{array}$ & $\begin{array}{c}0.107^{* *} \\
(0.054)\end{array}$ \\
\hline Family & $\begin{array}{c}0.057 \\
(0.074)\end{array}$ & $\begin{array}{c}0.067 \\
(0.074)\end{array}$ & $\begin{array}{c}0.057 \\
(0.075)\end{array}$ & $\begin{array}{c}0.055 \\
(0.074)\end{array}$ & & $\begin{array}{c}0.056 \\
(0.074)\end{array}$ & $\begin{array}{c}0.057 \\
(0.074)\end{array}$ \\
\hline Domestic company & $\begin{array}{c}0.029 \\
(0.063)\end{array}$ & $\begin{array}{c}0.034 \\
(0.062)\end{array}$ & $\begin{array}{c}0.028 \\
(0.064)\end{array}$ & $\begin{array}{c}0.029 \\
(0.062)\end{array}$ & & $\begin{array}{c}0.029 \\
(0.062)\end{array}$ & $\begin{array}{c}0.030 \\
(0.063)\end{array}$ \\
\hline Foreign company & & Omitted & Category & & & Omitted & Category \\
\hline Managers & $\begin{array}{c}0.180^{* *} \\
(0.074)\end{array}$ & $\begin{array}{c}0.175^{* *} \\
(0.079)\end{array}$ & $\begin{array}{c}0.182^{* *} \\
(0.079)\end{array}$ & $\begin{array}{c}0.170^{* *} \\
(0.074)\end{array}$ & & $\begin{array}{c}0.180^{* *} \\
(0.074)\end{array}$ & $\begin{array}{r}0.180^{* *} \\
(0.074)\end{array}$ \\
\hline Employees & $\begin{array}{c}-0.034 \\
(0.084)\end{array}$ & $\begin{array}{l}-0.013 \\
(0.085)\end{array}$ & $\begin{array}{c}-0.032 \\
(0.082)\end{array}$ & $\begin{array}{c}-0.028 \\
(0.083)\end{array}$ & & $\begin{array}{l}-0.034 \\
(0.085)\end{array}$ & $\begin{array}{l}-0.034 \\
(0.084)\end{array}$ \\
\hline State & $\begin{array}{l}0.139^{*} \\
(0.071)\end{array}$ & $\begin{array}{l}0.132^{*} \\
(0.072)\end{array}$ & $\begin{array}{c}0.140^{* *} \\
(0.070)\end{array}$ & $\begin{array}{l}0.139^{*} \\
(0.071)\end{array}$ & & $\begin{array}{l}0.139^{*} \\
(0.071)\end{array}$ & $\begin{array}{c}0.141^{* *} \\
(0.071)\end{array}$ \\
\hline Others & $\begin{array}{c}0.132^{* * *} \\
(0.049) \\
\end{array}$ & $\begin{array}{c}0.123^{* *} \\
(0.051)\end{array}$ & $\begin{array}{c}0.133^{* * *} \\
(0.049) \\
\end{array}$ & $\begin{array}{c}0.129^{* * *} * \\
(0.050)\end{array}$ & & $\begin{array}{c}0.131^{* * * *} \\
(0.048) \\
\end{array}$ & $\begin{array}{c}0.132^{* * * *} \\
(0.048) \\
\end{array}$ \\
\hline$\rho_{\nu \eta}($ std. error $)$ & $0.305(0.305)$ & $0.291(0.304)$ & $0.316(0.298)$ & $0.257(0.299)$ & $0.472 * *(0.208)$ & $0.276(0.343)$ & $0.395(0.357)$ \\
\hline Wald test & 1 & 0.916 & 1.124 & 0.738 & 5.14 & 0.647 & 1.224 \\
\hline Obs. censored & 1855 & 1855 & 1855 & 1855 & 1855 & 1775 & 2861 \\
\hline obs. & 3297 & 3331 & 3297 & 3298 & 3297 & 3217 & 4303 \\
\hline
\end{tabular}

Notes: i. $\dagger,{ }^{*},{ }^{* *}$ and ${ }^{* * *}$ represent $15,10,5$ and $1 \%$ significance, respectively.

ii. Standard errors clustered at the country level are in parentheses.

iii. Other control variables included in the $P R$ equation in all models: firm size, the number of competitors, the customers, a dummy variable for the firm being unprofitable in 2001, Collateral, the interest rate, the financing source, Manager education and age dummies, and sector of activity and country dummies.

iv. Control variables included in the Loan equation in models [A]-[E] and [G]: dummy variables for the main shareholder, Firm size, the number of competitors, the customers, a dummy variable for the firm being unprofitable in 2001, External audit, IAS, Training, Manager education and age dummies, and sector of activity and country dummies.

v. Control variables included in the Loan equation in model [F]: dummy variables for the main shareholder, Firm size, the number of competitors, the customers, a dummy variable for the firm being unprofitable in 2001, External audit, IAS, Training, Manager education and age dummies, sector of activity and country dummies, as well as dummy variables for the number of suppliers of the firm's main material input (None, 1-3, or more than 4), the percentage of sales in 2001 lost due to delivery delays from the material input suppliers, a dummy variable for the firm ever having had to resolve an overdue payment, and a dummy variable for the firm being a member of a business association.

vi. Variables excluded in model $[\mathrm{B}]=$ Percentage of sales in 2001 lost due to delivery delays; in model $[\mathrm{C}]=$ Member of a business association; in model $[\mathrm{D}]=$ a dummy variable for the firm ever having had to resolve an overdue payment; in model [E] $=$ the set of dummy variables for the main shareholder.

vii. Models $[\mathrm{A}]-[\mathrm{F}]$ are estimated with the estimation sample and model $[\mathrm{G}]$ with the BEEPS II sample. For the difference between these two samples, see subsection 4.1 in particular Table 1 and subsection 4.3 
Appendix

A Tables 
Table A1: Sensitivity of the marginal effects (and $\rho_{\epsilon \eta}$ )

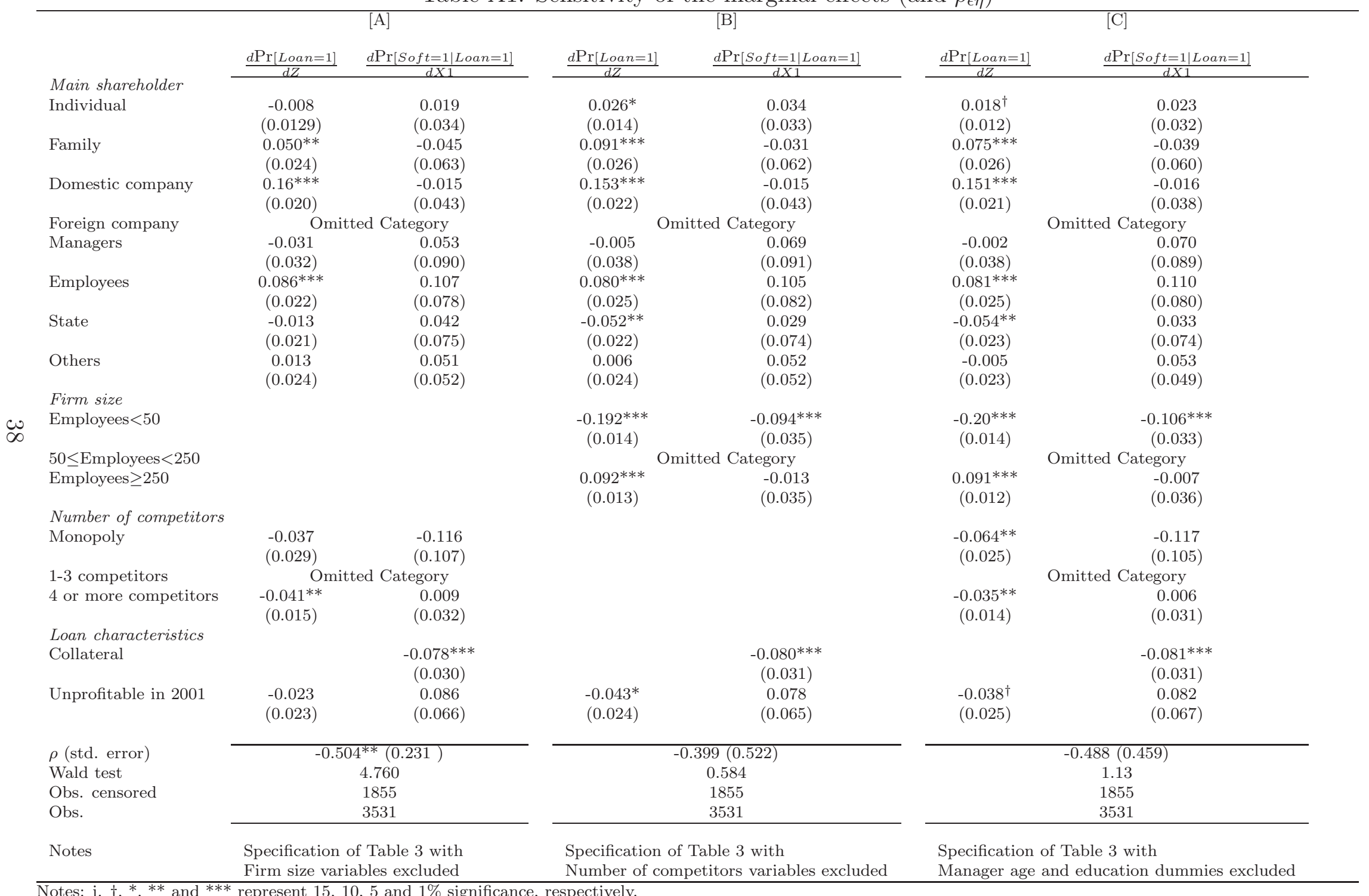

*** represent $15,10,5$ and $1 \%$ significance, respectively.

ii. Standard errors clustered at the country level are in parentheses. 
Table A2: Marginal effects for CIS and non-CIS firms

\begin{tabular}{|c|c|c|c|c|}
\hline & \multicolumn{2}{|r|}{ CIS } & \multicolumn{2}{|c|}{ Non-CIS } \\
\hline & $\frac{d \operatorname{Pr}[\operatorname{Loan}=1]}{d Z}$ & $\frac{d \operatorname{Pr}[\text { Soft }=1 \mid \text { Loan }=1]}{d X 1}$ & $\frac{d \operatorname{Pr}[\text { Loan }=1]}{d Z}$ & $\frac{d \operatorname{Pr}[\text { Soft }=1 \mid \text { Loan }=1]}{d X 1}$ \\
\hline Individual & $\begin{array}{l}-0.005 \\
(0.024)\end{array}$ & $\begin{array}{c}0.063 \\
(0.049)\end{array}$ & $\begin{array}{c}0.048^{* * *} \\
(0.017)\end{array}$ & $\begin{array}{l}-0.013 \\
(0.044)\end{array}$ \\
\hline Family & $\begin{array}{c}0.014 \\
(0.043)\end{array}$ & $\begin{array}{l}-0.042 \\
(0.104)\end{array}$ & $\begin{array}{c}0.115^{* * *} \\
(0.031)\end{array}$ & $\begin{array}{l}-0.073 \\
(0.070)\end{array}$ \\
\hline Domestic company & $\begin{array}{c}0.182^{* * *} \\
(0.047)\end{array}$ & $\begin{array}{c}0.046 \\
(0.033)\end{array}$ & $\begin{array}{c}0.134^{* * *} \\
(0.024)\end{array}$ & $\begin{array}{c}-0.042 \\
(0.062)\end{array}$ \\
\hline Foreign comp. & \multicolumn{2}{|c|}{ Omitted Category } & \multicolumn{2}{|c|}{ Omitted Category } \\
\hline Managers & $\begin{array}{c}0.050 \\
(0.038)\end{array}$ & $\begin{array}{c}0.155^{* *} \\
(0.066)\end{array}$ & $\begin{array}{l}-0.066 \\
(0.053)\end{array}$ & $\begin{array}{c}-0.064 \\
(0.134)\end{array}$ \\
\hline Employees & $\begin{array}{l}0.114^{\dagger} \\
(0.076)\end{array}$ & $\begin{array}{c}0.202^{* * *} \\
(0.059)\end{array}$ & $\begin{array}{c}0.006 \\
(0.034)\end{array}$ & $\begin{array}{l}-0.012 \\
(0.133)\end{array}$ \\
\hline State & $\begin{array}{l}-0.055^{\dagger} \\
(0.038)\end{array}$ & $\begin{array}{c}0.127^{* *} \\
(0.057)\end{array}$ & $\begin{array}{c}-0.056^{*} \\
(0.032)\end{array}$ & $\begin{array}{l}-0.037 \\
(0.079)\end{array}$ \\
\hline Others & $\begin{array}{l}-0.031 \\
(0.033)\end{array}$ & $\begin{array}{c}0.236^{* * *} \\
(0.077)\end{array}$ & $\begin{array}{c}0.038 \\
(0.032)\end{array}$ & $\begin{array}{c}0.018 \\
(0.044)\end{array}$ \\
\hline \multicolumn{5}{|l|}{ Firm size } \\
\hline Employees $<50$ & $\begin{array}{c}-0.21^{* * *} \\
(0.029)\end{array}$ & $\begin{array}{c}-0.122^{* * *} \\
(0.032)\end{array}$ & $\begin{array}{c}-0.189^{* * *} \\
(0.023)\end{array}$ & $\begin{array}{c}-0.096^{* *} \\
(0.047)\end{array}$ \\
\hline $50<$ Employees $<250$ & \multicolumn{2}{|c|}{ Omitted Category } & \multicolumn{2}{|c|}{ Omitted Category } \\
\hline Employees $\geq 250$ & $\begin{array}{l}0.056^{* *} \\
(0.027)\end{array}$ & $\begin{array}{c}-0.007 \\
(0.071)\end{array}$ & $\begin{array}{c}0.143^{* * *} \\
(0.016)\end{array}$ & $\begin{array}{c}-0.006 \\
(0.032)\end{array}$ \\
\hline \multicolumn{5}{|c|}{ Number of competitors } \\
\hline Monopoly & $\begin{array}{l}-0.031 \\
(0.143)\end{array}$ & $\begin{array}{r}-0.059 \\
(0.092)\end{array}$ & $\begin{array}{l}-0.099 \\
(0.075)\end{array}$ & $\begin{array}{c}-0.140 \\
(0.143)\end{array}$ \\
\hline $1-3$ competitors & \multicolumn{2}{|c|}{ Omitted Category } & \multicolumn{2}{|c|}{ Omitted Category } \\
\hline 4 or more competitors & $\begin{array}{l}-0.045 \\
(0.031)\end{array}$ & $\begin{array}{c}0.044 \\
(0.049)\end{array}$ & $\begin{array}{l}-0.025^{\dagger} \\
(0.016)\end{array}$ & $\begin{array}{c}-0.029 \\
(0.043)\end{array}$ \\
\hline \multicolumn{5}{|l|}{ Loan characteristics } \\
\hline Collateral & & $\begin{array}{c}-0.124^{* * *} \\
(0.045)\end{array}$ & & $\begin{array}{c}-0.070^{* *} \\
(0.028)\end{array}$ \\
\hline Unprofitable in 2001 & $\begin{array}{l}-0.016 \\
(0.042) \\
\end{array}$ & $\begin{array}{c}0.221^{* *} \\
(0.097) \\
\end{array}$ & $\begin{array}{c}-0.053^{* *} \\
(0.022) \\
\end{array}$ & $\begin{array}{c}0.043 \\
(0.068) \\
\end{array}$ \\
\hline Obs. censored & \multicolumn{2}{|r|}{1039} & \multicolumn{2}{|r|}{816} \\
\hline Obs. & \multicolumn{2}{|c|}{1740} & \multicolumn{2}{|r|}{1791} \\
\hline Notes & \multicolumn{2}{|c|}{$\begin{array}{l}\text { Specification of Table } 3 \text { with Manager age } \\
\text { and education dummies excluded, and } \\
\text { considering only CIS countries }\end{array}$} & \multicolumn{2}{|c|}{$\begin{array}{l}\text { Specification of Table } 3 \text { with Manager age } \\
\text { and education dummies excluded, and } \\
\text { considering only Non-CIS countries }\end{array}$} \\
\hline
\end{tabular}


Table A3: Marginal effects with an alternative definition of Soft

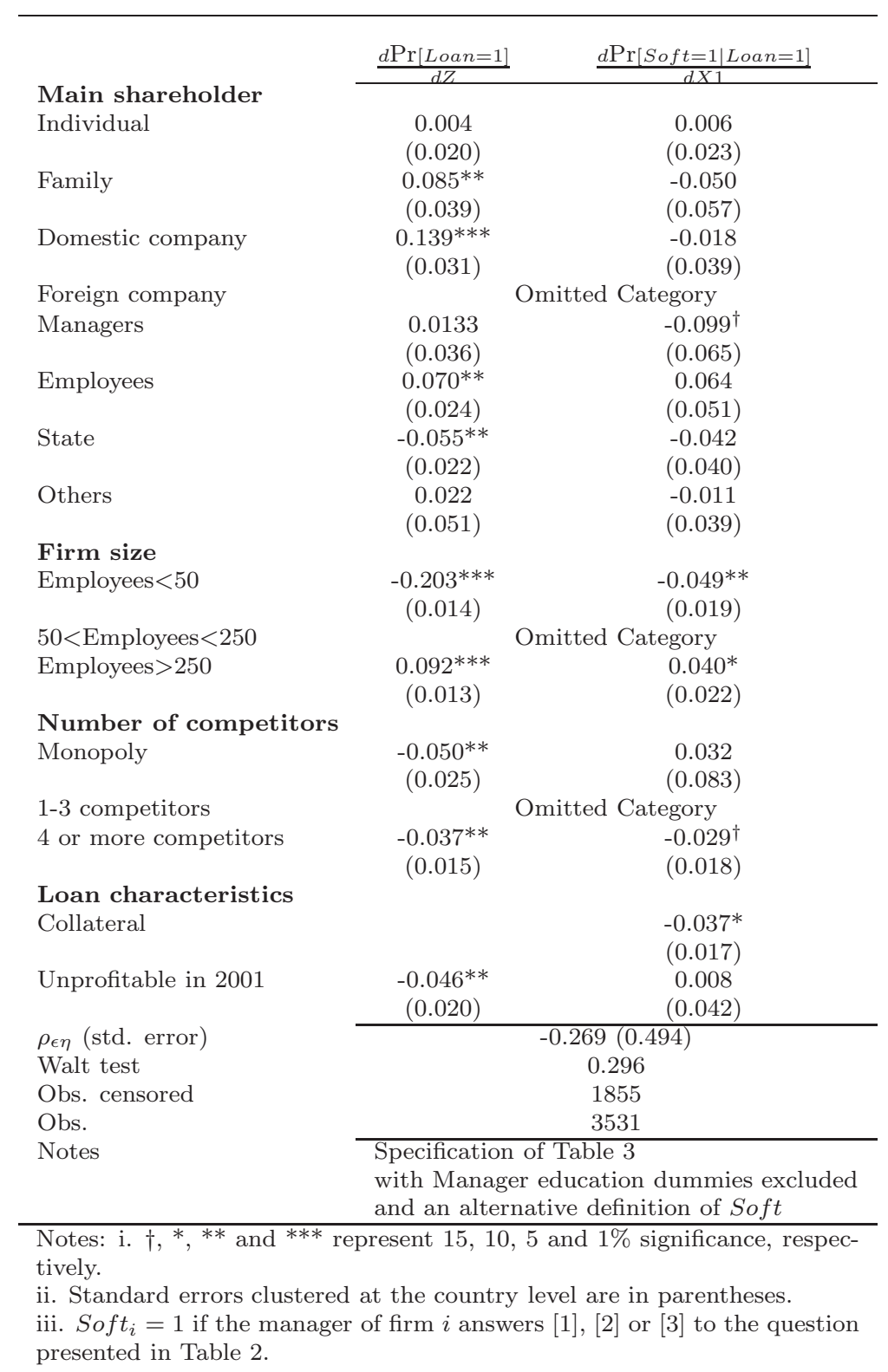

